\title{
METADISCOURSE MARKERS IN THE UNDERGRADUATE THESIS INTRODUCTION WRITTEN BY ENGLISH DEPARTMENT STUDENTS IN UNIVERSITY OF BENGKULU
}

\author{
Putri Agustinos \\ Universitas Bengkulu \\ putri.agustinos27@gmail.com \\ Safnil Arsyad \\ Universitas Bengkulu \\ safnilarsyad@gmail.com \\ Syahrial \\ Universitas Bengkulu \\ eric.syahrial@gmail.com
}

\begin{abstract}
This research is aimed to find metadiscourse form and metadiscourse category which are dominantly used in the undergraduate thesis introduction written by English Department students of Bengkulu University. The documentation technique and checklist are used in this research. Fifteen undergraduate thesis introductions by English Department students were analyzed by using mix method quantitative and qualitative, along with descriptive approach. From the result it was found that English Department students dominantly used interactive metadiscourse markers category and transition metadiscourse markers form in their writing. However, English Department students used of metadiscourse markers were still limited to the use of and, or, also but metadiscourse markers.
\end{abstract}

Key Words: Undergraduate theses introduction, metadiscourse markers, Indonesian authors, English students.

\section{INTRODUCTION}

Writing is a form of communication which often considered as one of the most complex activities. In addition, it also functions to convey information and depict the information through the organization of the text, also engage with the readers as to how they should understand it. Thus, it involves a series of actions to have a good writing, including a brainstorming of the content, diction picking for the good quality of a text, and attaching appropriate discourse elements in order to achieve the objective of writing, especially for academic purposes.
Abounding EFL writers struggle in adapting their prose for the reader (ReddBoyd and Slater, 1989). It is caused by the differences in writers' standard that are familiar with from their home communities and cultures. That is to say, there are needs to use more appropriate discourse elements and writing tools as a means to increase the comprehension of writers work toward the readers in EFL context. However, most of the EFL Learners such as in University of Bengkulu, specifically English Department students have little knowledge regarding the elements of academic writing such as discourse markers, metadiscourse markers, 
coherence and cohesion between each paragraph and appropriate diction.

It is quite difficult for the students to achieve the standard of writing performance. Meanwhile, their writing performance is crucial as it is one of the objectives that will decide whether they will be able to take a further step to conduct a research and writing their thesis.

These problems occurred based the variety of reasons. Alwasilah (2001) observed that writing is the most neglected skill in Indonesian academic institutions. Alwasilah (2011) said that Writing is less practiced and also taught unprofessionally. Writing is the most exalted language skill, yet it has been the most neglected one of our education. Most of the teachers and instructor lack of teaching writing skill elements. That is to say, the instructor often misunderstands the nature of writing and teaching strategies toward the learners.

Some previous studies have shown the use of metadiscourse markers in academic writing of ESL learners majoring in science and agriculture are able to make the writing better in terms of coherence, cohesion, and reader engagement (Dastjerdi, et.al., 2010; Karimi, et al., 2013; Estaji, et. al, 2015). The role of metadiscourse also has been widely acknowledged: "metadiscourse is known to be an effective technique for improving writing and a means, to render textbooks more considerate and readerfriendly." (Cheng \& Steffensen 1996, Crismore 1984, Hyland 1998; 1999). It is clear that metadiscourse helps writers to convey the message in the text for it makes the text engage the readers to a certain extent. While the data of the research was taken from ESL learners in science and agriculture major thesis introduction, in this research the author use English education undergraduate thesis introductions as the data.
Anwardeen et al.'s (2013) conducted a study focused on college students; this study examined the metadiscourse use of first-year Malaysian undergraduates' persuasive writing. Anwardeen (2013) said it is important to examine the writing of this group of writers because they will enter the university an encounter abounding challenges regarding writing in English. While in this research the author use English education undergraduate thesis introduction as the object.

Hyland (2004) examined the purposes and distributions of metadiscourse in a corpus of 4 million words from 20 Masters and 20 Ph.D. dissertations written in English by Chinese students from five Hong Kong universities. He pointed out that in dissertation and thesis writing, metadiscourse was particularly important due to the fact that it represents the students' attempt to present their texts in the ways that are acceptable to examiners as they represent the wider professional disciplinary community in the students' areas of study. The findings indicate that there were a balance between interactive (organizational) and interactional (evaluative) forms (239.8 vs. 225 per 10,000 words). And the most frequent subcategories were hedges, transitions, evidential and engagement markers. The difference between this study and the research by Hyand (2004) is the object which was English education undergraduate thesis introduction.

The EFL learners, particularly Indonesian students of English in University of Bengkulu have to write an undergraduate thesis as the prerequisite requirement to graduate from the university. However, the EFL students entered the university with differing English proficiency levels. And upon entering the university, certain courses will be conducted in English and the students have to write their assignments in English. As a result of these challenges and the 
keenness of wanting to know how the Indonesian student of the English uses of metadiscourse markers in their undergraduate thesis, the researcher will conduct the study.

To sum up, it has been proven that lots of research regarding the use of metadiscourse markers is effective to improve the learners writing quality at all levels of studies. However, what makes this research different to the previous studies is the object of the study, which is undergraduate thesis of English education undergraduate thesis introduction that has little attention to the previous researchers that mainly focus on ESL learners. Furthermore, the researcher will find out the dominant metadiscourse form and the dominant metadiscourse categories in the undergraduate thesis introduction written by English education students in University of Bengkulu.

\section{METHOD}

This research used checklist and documentation technique. The design of this research is descriptive, using mix method, quantitative and qualitative. The quantitative result were shown to depict the percentages of occurences, wehreas qualitative result were shown in order to describe, explain, and illustrate the findings in detail. In this research, the data were collected from undergraduate thesis introductions written by English education students in University of Bengkulu.

The object of this research is fifteen undergraduate thesis introductions which were submitted in 2017. According to Gay \& Diehl, (1992), generally the number of respondents acceptable in a study depends upon the type of research involved descriptive, correlational or experimental. For descriptive research, the sample should be $10 \%$ of the population. But if the population is small (less than 100 corpus) then $20 \%$ may be required. Thus, to take the sample of the study, the researcher used $20 \%$ sample selection ( 15 theses) due to the fact that the population number of the object was only 70 theses in 2017. This technique also has been used by several international researches (Miller; 1995, Pisanupoj; 1998, Phillippe; 2014), thus the validity of the method could be ensured.

The instruments used in this research comprised a metadiscourse markers check list from Hyland (2005) and his formula to measure the differences between the two variables in general and in terms of the length of the introduction. The reason of utilized these tools was because the criteria of assessment which were suitable for academic writing such as thesis and dissertation (Alvero, 2016). The model used was based on Hyland (2005) model in which he defined metadiscourse as a functional category that assists writers to express a viewpoint and engage with readers as members of a particular community (Hyland, 2005). The great merit of this model, it attempted at offering a clear picture of the concept of metadiscourse based on a functional approach. This model was based on three principles that focus on the distinction between metadiscoursal and propositional aspects of discourse, the writer-reader interaction during the text, and the internal relations established in the text.

There were some procedures in the data analysis. First and foremost, the data were gathered from University library. Second, the samples are read by the researcher. Third, 3. The forms of metadiscourse signals in the undergraduate thesis introduction section were classified using table matrix based on Hyland (2005). Fourth, the categories of metadiscourse signal in the undergraduate thesis introduction section were classified by table matrix based on Hyland (2005).Fifth, the data inserted into matrix table, which helped the researcher to classify, to identify 
and to analyze the data. Sixth, the researcher analyzed the data from the corpus. Seventh, the researcher asked a co.researcher to validate the findings by analyzed the sample of undergraduate thesis introduction section.

First of all, the researcher gave the information to the co-researcher about the types and the use of metadiscourse undergraduate thesis in the introduction section followed by the examples. Second, the co-researcher analyzed the undergraduate thesis introduction section based on the 6 out of 15 samples of the corpus that the co-researcher picked using random sampling technique. Third, the co.researcher inserted data to the checklist instruments that have been made by the researcher. Finally, the co-researcher wrote the result of the analysis.

\section{RESULT AND DISCUSSION}

There were 1955 metadiscourse markers found in all undergraduate theses introductions. The result of this research showed that the metadiscourse markers category dominantly used by Indonesian authors was interactive metadiscourse (70\%), and the metadiscourse markers form that dominantly used by Indonesian authors was transition markers (32\%).

\section{Categories of Metadiscourse Markers Found In The Undergraduate Thesis Introduction}

Research question number 1 asked about the dominant category of metadiscourse markers used in the undergraduate theses introduction section of English education students in Bengkulu Unversity.

Table 1.Category of Metadiscourse Markers Used In Undergraduate Theses Introduction

\begin{tabular}{|r|c|c|}
\hline Metadiscourse & Frequency & Percentage \\
\hline Interactive & 1340 & $70 \%$ \\
\hline Interactional & 615 & $30 \%$ \\
\hline Total & $\mathbf{1 9 5 5}$ & $\mathbf{1 0 0 \%}$ \\
\hline
\end{tabular}

From 1955 metadiscourse found, 615 metadiscourse markers were interactional and 1340 metadiscourse markers were interactive metadiscourse markers. The analysis can be seen in Appendices 4. Table 4.2 shows the number and percentage of the dominant category of metadiscourse markers used in theses introduction is the interactive metadiscourse (70\%) while interactional metadiscourse becomes the latest (30\%).

Interactive metadiscourse according to Hyland (2005)" functions to help to guide the reader through the text. It expresses relations between main clauses refer to discourse, sequence or stages refer to information in other parts of the text refer to information from other texts elaborate propositional meanings." That is to say, the result indicated that English Department students were concerned about the awareness of making the reader participate and also accommodate its probable knowledge, interest, rhetorical expectations and processing abilities. This is considered as good because Hyland (2005) also claimed that interactive metadiscourse used to set out arguments that will recover the writer's preferred interpretations and goals. Below is the example of metadiscourse markers categories used in the undergraduate theses introduction.

\section{Example 1:}

Based on that phenomenon, a language learner is suggested to use an appropriate learning strategy in order to help them in mastering speaking skill. Employing language learning strategies to develop speaking skill seems necessary for language learners because speaking the new language often causes the greatest anxiety among other language skill The teacher should be aware of those differences in order to find an appropriate way to teach the students. One of the students' differences that strongly influenced the students' 
achievement in learning a language is their learning strategies. In order to enhance their speaking ability, they may have a particular or different learning strategy that different from anyone else. (Thesis No. 3)

In example 1, the writer uses interactive categories to emphasize the contextualization and the meaning of the text. The result of an interactive process between the writer to the reader of the text in which the writer chooses forms and expressions which will best convey his or her material, stance and attitudes (should, chose, seems, believe).

The result also similar to Hyland and Tse (2004) research on metadiscourse in postgraduate dissertations which shows that interactive metadiscourse is dominantly used in the ESL dissertations. Cao and $\mathrm{Hu}$ (2014) study also support this findings in their research that showed the interactive metadiscourse are more dominant in the research articles of Applied linguistics, Education and Psychology research articles. The similarities are based on the use of interactive metadiscourse in the academic discourse. That is to say, the interactive metadiscourse are dominantly used in this regard, because it functions as important logical markers that serve the useful function to sorting out similarities, identifying differences, comparing empirical results with theoretically-derived hypotheses, and establishing causal links between propositions and variables.

The interactive dimension was principally achieved through metadiscourse. It was necessary to note that the type and distribution of metadiscourse in the sample reveals their very different contexts of reception. In the first example (Thesis No. 3 ) the researcher found the careful qualifications and exceptions characteristic of philosophical precision, with much of the metadiscourse functioning to hedge propositions (seems and should).

\section{Example 2,}

They are so enthusiastic to see it. If they listen to the magic trick, they will go to the place to see it. And some of them believe with what they see in the magic. That is why the researcher chooses this movie. As we know, not everyone can easily understand a movie because movie or film uses oral language. Many implicit meanings in a movie or film can be found. It makes them difficult to understand the meanings or messages contained in the movie or film. Due to the difficulty in understanding meaning of the movie or film, the researcher chooses one of the ways to learn English which is by using movie script, because it can help the students or the audience to understand and to catch the meaning of the movie or film itself. (Thesis no. 10)

The second extract (Thesis No. 10), the writer use interactional metadiscourse even though it is not higher than the interactive netadiscourse. The writer endeavors to engage his readers by using general personal pronouns (we) to stress the relevance of his discussion and its connection to the common experience of both readers and writer which belongs to the interactional category. The writer also made assumptions about what readers 'know' (not everyone can easily understand a movie because movie or film uses oral language) asides in parentheses which seek to engage the readers as active participants in the discourse.

Ozdemir and Longo (2014) found that Turkish students also use interactional metadiscourse, even though it is below that the use of interactive metadiscourse markers. The findings indicate that English education students and Turkish students have similarities in indicate the awareness concerning the level of personality of their arguments. 
Form of Metadiscourse Markers Found In The Undergraduate Thesis Introduction

Research question number 2 asked about the form of metadiscourse markers that dominantly used by English department students in their theses introduction section.

Table 2. Forms of Metadiscourse Markers Used In Undergraduate Theses Introduction

\begin{tabular}{|l|c|c|}
\hline \multicolumn{1}{|c|}{$\begin{array}{c}\text { Form of } \\
\text { Metadiscourse }\end{array}$} & Frequency & Percentage \\
\hline Transition & 611 & $32 \%$ \\
\hline Frame Markers & 381 & $19 \%$ \\
\hline $\begin{array}{l}\text { Engagement } \\
\text { Markers }\end{array}$ & 201 & $10 \%$ \\
\hline Code Glosses & 179 & $9 \%$ \\
\hline Evidentials & 144 & $7 \%$ \\
\hline Hedges & 115 & $6 \%$ \\
\hline Self-Mention & 108 & $6 \%$ \\
\hline Boosters & 105 & $5 \%$ \\
\hline $\begin{array}{l}\text { Attitude } \\
\text { Markers }\end{array}$ & 56 & $3 \%$ \\
\hline $\begin{array}{l}\text { Endophoric } \\
\text { Markers }\end{array}$ & 25 & $1 \%$ \\
\hline \multicolumn{1}{|c|}{ Total } & 1955 & $100 \%$ \\
\hline
\end{tabular}

From 1955 metadiscourse found, 611 metadiscourse were transition, 381 metadiscourse were frame markers, 201 metadiscourse were engagement markers , 179 metadiscourse were code glosses, 144 metadiscourse were evidential, 115 metadiscourse were hedges, 115 metadiscourse were boosters, 108 metadiscourse were self-mention, 56 metadiscourse were attitude markers, and 25 metadiscourse were endophoric markers.

Table 2 shows the number and percentage of metadiscourse markers form found in undergraduate theses. The metadiscourse form which dominantly used was transition. As can be seen from the table, the total 32\% (611 transitions) found in the theses, 19\% (381 frame markers) found in the theses, 10\% (201 engagement markers) found in the theses, $9 \%$ (179 code glosses) found in the theses, 7\% (144 evidentials) found in the theses, 6\% (115 hedges) found in the theses, 6\% (108 selfmention) found in the theses, 3\% (56 attitude markers) found in the theses, and $1 \%$ ( 25 endophoric markers) found in the theses from total 1955 metadiscourse markers. It clearly proved the dominant metadiscourse markers form used by English education students in their undergraduate theses were transitions. Below are the examples of metadiscourse markers form used in the undergraduate theses introduction.

\section{Example 3:}

In this case, every student had the different ability on each language skill. Some students were good at writing skill but they were poor in speaking skill. (Thesis 1 )

In example 3, the use of conjunction but has distinct functions which can be seen as follows: (a) the conjunction but function ideationally, connecting propositions and signaling the writer's understanding of the relations between ideas by creating links with statement about the students ability (b) in the other hand, they function interactionally to engage the reader as participant in the discourse, recognizing their need for explicit signaling of links in the argument.

It is supported by Hyland (2005) who said transition in some cases, deal with the logic of discourse: they work to cement the text together. In other cases, they concern the logic of life: they function to extend, elaborate or enhance prepositional meanings. Therefore, it can be seen that in this example, it fits with Hyland (2005) claim in regard of transition.

\section{Example 4:}


In this research, the researcher focuses on the language skills (listening, speaking, reading and writing). Based on the problem above, the researcher wants to gain information of English textbook grade XI published by Kemendikbud 2014 meet the balance material proportion or not based on the goal of English subject's syllabus for Senior High School. So the researcher wants to do a research entitled "An Analysis of the Proportion of Language Skills in English Textbook Grade XI Published by Kemendikbud 2014". (Thesis 2)

In example 4, the author used frame markers want to and so to announce the discourse goal. The author also provides framing information about the element of the discourse.

Marco (1998) in his study claimed that frame markers can have several functions either to shift the topic or to indicate steps in an experiment as the demonstrator moves through a process. In the example 4, it clearly is seen that the frame markers used to indicate the variables and steps in the research similar to Marco's findings.

\section{Example 5:}

In grammar, there is a term called clause that we find often in our textbook. A clause has the same function as a sentence. It contains a subject and a verb (Azar, 1999). A clause is divided into independent clause and the dependent clause. (Thesis No.15)

In example 5, the author used engagement markers we (inclusive) to engage with the reader. According to Hyland (2005) in engagement markers, heterogeneous group of devices is used to directly address the reader, and as can be seen, the second language writers were far more likely to employ these in their essays. It is supporting the finding because the second-person pronouns were used significantly more by the non-native English writers in this corpus, largely to urge the reader to learn from the personal experience of the writer. In fact, not only for ESL as the previous study proven by Hyland but second - person pronouns also used in EFL writing as found in this study.

\section{Example 6}

There is also word formation process involved. The base word is "tense" which means "stressed tightly". To form the new medical term, the word "tense" is adding by affixes, they are hyper- as a prefix which means "over" or "excess" and -ion as a suffix which indicates an action or process. In short, the medical term "hypertension" means abnormally high (over) blood pressure. From this term, the point is by adding affixes, a free morpheme can create the new term, particularly in the field of medical. This process is called derivation; one of word formation types in morphology study. (Thesis 12)

In example 6, the author used code glosses which means and called to elaborate the terms that she or he had mentioned. Hyland (2005) claimed that code glosses functions to explain define or clarify the sense of a usage, sometimes putting the reformulation in parentheses or marking it as an example. That is to say, code glosses provided additional information, by rephrasing, explaining or elaborating what has been said, to ensure the reader is able to recover the writer's intended meaning. This claim supports the finding for in the example 6 , the author use which means to provide alternative information about the term that previously said. It is also similar to the extend that the writer in this case reflected the writer's predictions about the reader's knowledgebase (that the reader need more explanation) and were introduced by phrases such as this is called, in the other hand, that is, this can be 
defined as, for example, etc. which marked off by parentheses.

This finding is also supported by the study from Tarrayo and Duque (2011) who found that Editorialists seem to use code glosses to provide adequate clarifications and exemplifications in the proposition or content. Furthermore, the use of different code glosses to explain, rephrase, expand, or exemplify information tends to validate the elaborate and change-oriented (Mohamed \& Omer, 2000) rhetorical pattern of Philippine English as an Outer-CircleEnglish variety. Similar to the finding, English department students use code glosses in the undergraduate thesis introduction to establish an engagement to the readers for providing better explanation in the term, topic, or ideas written by the author.

\section{Discussion}

The first finding in this study is the dominant category of metadiscourse markers used in the undergraduate theses introduction that is interactive metadiscourse. According to Hyland (2005), interactive metadiscourse functions to help the reader through the text. It is concerned the writer awareness of a participating audience and the ways he or she find out to accommodate its probable knowledge, interests, rhetorical expectations and processing abilities. In this research, it is found that the students used interactive metadiscourse. That means, the English education students had a purpose to shape and constrain a text to meet the needs of the particular reader, set out arguments in order to recover their preferred interpretations and goals.

The finding of this study confirmed the finding of Duruk (2017) who also found interactive metadiscourse was dominantly used in Turkish writer's dissertations as it was the bridge between text information and writer's interpretation. It also supported the finding of Hyland and Tse (2004) who found out that interactive metadiscourse was frequently used in postgraduate writings. It showed that the writer had an enormous attempt to engage with readers and present their competency and credibility in the ideologies and practices of their disciplines for they provided more citations in their writing. Similar to the finding of this study, the dominant use of interactive metadiscourse markers by English education students presumably happened because the students think it is necessary to elaborate and convey the ideas in the introduction section of their thesis.

The second finding of this study was the dominant forms used in the undergraduate theses introduction which is transitions. Transition used to express the semantic relation between main clauses or sentences. According to Hyland (2004) transitions and hedges that conjunctioned mark between clauses or sentences can be oriented to either propositional or interactional meanings. This is often used in academic writtent discourse because people have tendencies to see it as expressing connection between ideas probably as a result of their primarily ideational orientation of the world. In particular, when referreing to what the researcher did, the transition is more common form which were used by the students. It is presumably because in the introduction, the students need to convey the problem and the solution that they offered, meanwhile when they use hedges, it shows uncertainty to certain extent that might blur the objective of the research.

The finding of this study confirmed Lee and Casal (2014) who found that the transitions were the dominant form of metadiscourse markers used in Ph.D. English and Spanish METRADs. According to Lee and Casal (2014), their study found that constituting nearly $33 \%$ of all metadiscourse in the E-METRAD and over $25 \%$ in the SMetrad, the most frequent metadiscourse in both sub corpora was transitions. Referring 
to this study, the transition is used $32 \%$. It illustrates that the use of transition in the undergraduate students of English education students are good.

The findings also in line with the study of Shi and Han (2014) who found that undergraduate students who have high score writing based on College English Test Band (CET-4) use more transitions in their writing compared to other forms of metadiscourse. It also supported Tan (2014) findings in undergraduate Malaysian students who used transitions dominantly in their persuasive writing. The use of transitions as the dominants form perhaps caused by the fact that transitions as fundamental linguistic elements have been taught in grammar and writing classes simultaneously. Therefore, students were aware of the use of transitions markers to link clauses or sentences in order to increase the coherent in their writing. However, referring to this study, the metadiscourse form used in the undergraduate thesis introduction were limited to the use of metadiscourse markers and, or, also but. Meanwhile the previous study showed a variety use of transition metadiscourse markers such as moreover, besides, and therefore. It is probably because the English education students have limited knowledge about metadiscourse markers and its use in academic writing such as in the undergraduate thesis introduction

It can be seen that English Education students use good portion of metadiscourse markers in their academic writings based on the metadiscourse marker form and metadiscourse category used in the theses introduction. On the other hand, they still need to develop their use of metadiscourse markers so it will not only limited to the use of and, or, and but.

\section{CONCLUSION AND SUGGESTION}

The research aims to find metadiscourse markers category and metadiscourse markers form used by English department students in theses introduction section.

From the result, it was found that the dominant category of metadiscourse markers in the undergraduate thesis of English education students in University of Bengkulu is interactive metadiscourse. In accordance to the previous studies, it is considered as good because interactive metadiscourse is dominantly used in written academic discourse.

The second finding showed that the dominant form of metadiscourse markers used by English Department students in University of Bengkulu is transition which is similar to the previous studies that also dominantly use transition. However, the metadiscourse markers that used by English Department students still limited to metadisourse and, or, also but. It is probably caused by the limited knowledge of the English education students in regard of metadiscourse markers varieties.

\section{Suggestion}

Based on the conclusion above, it is suggested that firstly, English Education study program students and lecturers should be attentive in regards to the use of metadiscourse markers in order to create a good introduction section. It is considered really important as undergraduate students have to write theses introduction in their last year. By doing so, their English theses, dissertation, or any written discourse will be more acceptable and readable by international writers and native learners. It is highly encouraged that lecturers put metadiscourse markers as an integrated topic to be learned in Report Writing, Academic Writing and Discourse Analysis subject. The reason being is to make the students have a better understanding about metadiscourse markers and the students will be able to apply it in their writings. Second, since this study is limited to the use of metadiscourse markers in the 
undergraduate thesis intoduction of English education students, the future researchers could further analyze the appropriate use of metadiscourse markers under the similar corpus. It may lead to new contributive findings in regards of metadiscourse markers.

\section{REFERENCES}

Atai, M. R., \& Sadr, L. (2008). A crosscultural study of hedging devices in discussion section of applied linguistics research articles. Teaching English Language and Literature Society of Iran (TELLSI), 2(7),

Austin, J. L. (1962). How to do things with words. Oxford: Oxford University Press.

Barton, E. (1995). Contrastive and NonContrastive Connectives Metadiscourse Functions in Argumentation. SAGE Journals.Volume: 12 issue: 2, page(s): 219-239.

Beauvais, P. J. (1989). A speech act theory of metadiscourse. Written

Communication,6(1),11-30. http://dx.doi.org/10.1177/07410883 89006001002

Chan, S. \& Tan, H. (2010). Extracting and comparing the intricacies of metadiscourse of two written persuasive corpora. International Journal of Education and Development using ICT, 6(3), 124146. Open Campus, The University of the West Indies, West Indies.

Cheng, X and Steffensen, M. (1996). Metadiscourse: A technique in improving students writing. Research in the teaching of English. Journal of Pragmatics. Elsevier
Crismore, A. (1982). The metadiscourse component: understanding writing about reading directives. Avon.

Crismore, A. (1984). The rhetoric of social studies textbooks: Metadiscourse. Journal of Curriculum Studies, 16 (3), 279-296.

Crismore, A. (1985). Metadiscourse in social studies texts. Technical Report, No. 366.

Crismore, A. (1989). Talking with readers: Metadiscourse as rhetorical act. New York: Peter Lang.

Crismore, A. et al. (1993). Metadiscourse in persuasive writing: a study of text written by American and Finnish university students. Written Communication.

Duszak, A. (1994). Academic discourse and intellectual styles. Journal of Pragmatics, 21, 291-313. doi:10.1016/0378-2166(94)90003-5

Falahati, R. (2006, February). The use of hedging across different disciplines and rhetorical sections of research articles. Proceedings of the 22nd North West Linguistics Conference (NWLC22), Burnaby: Simon Fraser University, 1, 99-112.

Halliday MAK. (1994). An Introduction to Functional Grammar. 2nd Edition, Edward Arnold.

Halliday MAK. (1985). An Introduction to Functional Grammar. 3rd Edition. London. Edward Arnold, London;

Halliday MAK. (2007). Language and education. London: Continuum.

Harris, Z. (1970). Linguistic transformations for information retrieval. In papers in structural and transformational linguistics. Dordrecht: D. Reidel. (Original work published 1959).

Hempel, S. Degand, L. (2008). Sequencers in different text genres: Academic writing, journalese, and fiction. 
Journal of Pragmatics, 40(4), 676693.

Hyland, K. (1994). Hedging in academic writing and EAP textbooks. English for Specific Purposes, 13(3), 239256.

Hyland, K. (1998). Persuasion and context: The pragmatics of academic metadiscourse. Journal of Pragmatics, 30, 437.

Hyland, K. (1999). Talking to students: Metadiscourse in introductory course books. English for Specific Purposes, 18 (1), 3-26.

Hyland, K, (2001a). Humble servants of the discipline? Self-mention in research articles. English for Specific Purposes, 20(3), 207-226.

Hyland, K. (2004). Disciplinary interactions: Metadiscourse in L2 postgraduate writing. Journal of Second Language Writing, 13(2), 133-151.

Hyland, K (2005). Metadiscourse: Exploring Interaction in Writing, 14 - 60. 218 -234 .

Intraprawat, P., \& Steffensen, M. (1995). The use of metadiscourse in good and poor ESL essays. Journal of Second Language Writing, 4(3), 253-272.

Martinez, A. C. L. (2004). Discourse markers in the expository writing of Spanish university students. IBERICA, 8, 63-80.

Mur Dueñ as, M.P. (2007). "I/we focus on ...": A cross-cultural analysis of self-mentions in business management research articles. Journal of English for Academic Purposes, 6(2), 143-162.

Nash, W. (1990). The Writing Scholar: Studies in Academic Discourse. Indiana University. SAGE Publications.
Richards, J.C. \& Schmidt, R. (2010). Longman dictionary of language teaching and applied linguistics (4th ed.). Harlow: Longman.

Redd-Boyd, T. and Slater, W. (1989). The effect of audience specification on undergraduates: attitude, strategies, and writing. Research in the Teaching of English, 23, 77-103

Schiffrin, D. (1980). Meta-Talk:

Organizational and Evaluative

Brackets in Discourse. Wiley

Online Library. Sociological Inquiry

Volume 50, Issue 3-4

https://doi.org/10.1111/j.1475-

682X.1980.tb00021.x

Steffensen, M. S.; Cheng X, (1996).

Metadiscourse and Text

Pragmatics: How Students Write

after Learning about

Metadiscourse. In: Bouton,

Lawrence F., Ed. Pragmatics and

Language Learning. Monograph

Series Volume 7,p153-70, 1996; see FL 024180.

Thompson, G. (2001). Interaction in academic writing: Learning to argue with the reader. Applied Linguistics, 22(1), 58-78.

http://dx.doi.org/10.1093/applin/22. 1.58

Thompson, E. S. (2003). Text-structuring metadiscourse, intonation, and the signaling of organization in academic lectures. Journal of English for Academic Purposes, 2(1), 5-20.

Vande Kopple W. (1985). Some exploratory discourse on metadiscourse. College Composition and Communication 1985;36: 82-93.

Vande Kopple W. (2002). Metadiscourse, discourse, and issues in composition and rhetoric. In E. Barton \& G. Stygall (Eds.), Discourse studies in composition. Gresskill, NJ: Hampton Press, Inc. 
Williams, Joseph M. (2011). Problems into

PROBLEMS: A Rhetoric of

Motivation. Practice \& Pedagogy.

Fort Collins, Colorado: The WAC

Clearinghouse.

Zarei, G. R. \& Mansoori, S. (2011). A contrastive study on metadiscourse elements used in humanities vs. non humanities across Persian and English. English Language Teaching, 4(1), 42-50. 